\title{
Categories of Legends Folktale of Minangkabau People's in West Sumatra
}

\author{
Hasanuddin WS, Emidar, Zulfadhli \\ Fakultas Bahasa dan Seni Universitas Negeri Padang, Indonesia \\ hasanuddinws@gmail.com
}

\begin{abstract}
This research article contains a discussion about the egends folkltale category of Minangkabau people's in West Sumatra. This research is descriptive qualitative research. The legends folktale of Minangkabau people's in West Sumatra was obtained from the narrative of informants. Categorical data is formulated through a search of the motive structure and role function the legends folktale the of Minangkabau people's in West Sumatra that has been collected. The study of legends folktale of the Minangkabau people's in West Sumatra uses structural study theory as used by Danandjaja (1984), Djamaris (1993 and 1994), Rusyana (2000). This is in line with that done by Proop (1928, 1967, 1987), Greimas (1979, 1990), Scoles (1974). Based on the research findings, the legends folktale of Minangkabau people's in West Sumatra with regard to the motive structure and role function, can be categorized into four categories, namely (1) folktale of religious legend, the legend of the meritorious and main people in the development of Islam in West Sumatra, (2) the folktale of the supernatural legends, the folktale that is considered to be true and has been experienced by someone to affirm the superstitious truth, (3) the folktale of individual legend, the folktale about certain characters as the main person, and (4) folktale of local legend, ie folktale related to a place, topography, name, and about its origin.
\end{abstract}

Keywords-category; folkltale; legends; Minangkabau people; West Sumatera

\section{INTRODUCTION}

Literary works will always attract attention because it reveals the deepest human appreciation, in the course of his life in all ages; everywhere in the world. Jassin (1983) states that, through literature as a result of art, the reader enters the experience of nations and peoples in history and society, exploring what was once thought and felt. Thus, literature can add wisdom and wisdom in life

The Indonesian nation in a cultural perspective is a nation that has a strong culture that is formed in a very long time. History has noted that the nation of Indonesia is a nation that has a high culture. This fact can not be denied because of the evidence of valuable precious remains that can still be found. Relics that prove the level of civilization of the Indonesian nation is not only material, such as temple buildings, inscriptions, ornaments on traditional houses or rice granaries, tools of daily life, but also in the form of relics which is moral-spiritual. From the cultural heritage of a moral-spiritual nature obtained valuable information about the concepts and patterns of thinking, patterns of behavior, customs, worship systems and beliefs, education and cultural traditions, as well as other things from the life of the ancestors of Indonesia.

In order to achieve national development objectives, efforts to explore, recognize, document and preserve the positive heritage of the Indonesian ancestor culture need to be done. This can enrich and reinforce the sense of pride of future generations of the nation's precious heritage. In addition, a good introduction to cultural heritage by future generations can reinforce the nation's tradition in responding to the increasingly tough future challenges of this era of globalization.

Cultural heritage in the form of moral-spiritual heritage or also known as intangible cultural heritage, one of which is obtained and known through the oral tradition of folktale that lives in a society. Folktale that is passed down through generations actually conveys the cultural values that are believed by the community to the next generation. According to Navis (1984), the cultural value of tradition as a type of pronunciation is a system of communication. Human life, and in itself human relations, is dominated over beliefs or beliefs. If it grows and develops, beliefs or beliefs are accepted as truth. Society's belief in something may well be beyond the general logic, but such a conviction according to Barthes (2003) can not be blamed. The thing to be aware of the beliefs of society is not a matter of right or not true, but how far it functions in fulfilling the social functions of people's lives. Therefore, in a condition where people believe in a tradition's values as truth and that it is believed to enable the emergence of communal solidarity, such beliefs can serve as propositions as science, inherited rules, and practiced by generation, form of memory and memories, ideas, or decisions that are believed. 
The Minangkabau community is one of the strong ethnic and exists in the archipelago. The identity of Minangkabau authenticity has contributed to the form of national culture, among others through language, art, and other aspects of tradition. The people who are strong and able to contribute their culture are strong, compact, and proud of their identity. Such a society grows because it has a "glue." The glue is certainly of fundamental values that can integrate Minangkabau society into a unified pattern of life (views, values of life, philosophy, etc.). One of the glue that is used can be said to be derived from the traditional values that can be found in the Minangkabau people's folktale in the form of folktale of legend, which is one kind of folktale that connects the story that is told with the situation and condition of the area where they live.

In the right and constructive conditions, values can give the spirit of the dynamics of people's lives where the basic values are alive and evolving; cultivate and develop community integrity, create social solidarity, foster pride in group identity, and be useful to establish communal harmony. Therefore, in essence every society, both traditional society and modern society values that occur on wisdom for a harmonious.

In the case of folktale, it is known that there are types of folktale of myths, fairy tales, and legends. One type of three folktale that thrives and is inherited by the Minangkabau people is the folktale of legend. The legend's folktale resides in the Minangkabau's main residence area, which is in the adat luhak (mountains) and rantau (coastal) areas. The present-day administration of Indonesia government, the Minangkabau people's is in the region in which they live is called the West Sumatra Province. It is interesting and important to examine the folktale of the Minangkabau people's legends. As explained earlier in the legends folktale is preserved the philosophy of life, concepts, behavior, perceptions, and issues about Minangkabau people. The research to formulate the legends folktale category of Minangkabau people's in West Sumatra is one of the stages to be able to answer the question of some formulas the social behavior of Minangkabau people. The formulation can be seen as the basic values that have "glued" the ethnic Minangkabau community into a strong ethnic and exist in this archipelago.

The study of the legends folktale category of Minangkabau people's in West Sumatra was conducted as a study of the narrative oral literature with a folklore perspective. Things like this done by Danandjaja (1984), Djamaris (1993), and Rusyana (2000). The things done by Danandjaja, Djamaris, and Rusyana are in line with what Proop did (1928, 1967, and 1987), Greimas (1979 and 1990), and Scholes (1974). Thus, the category study of the legends folktale of Minangkabau people's in West Sumatra is the foundation of the fulcrum is the study of structures.

Propp (1928) is the first structuralist to conduct a genuine study of the narrative structure while providing a new meaning to the dichotomy of the fibula and sjuzet. Proop (1987) concludes that the narrative of the hundred Russian folktale he collects has the same structure. What he means is that in the folktale the principals and their traits can be fickle, but their actions and functions are the same, unchanged. Proop views sujzet as a non-plot theme as understood by formalists. According to Proop (1987) the motive is an important element because the motifs that form the theme. Motifs in the structure of folktale can be divided into three, namely the perpetrators, actions, and patients.

Greimas (1979) conducted a narrative analysis of the story text. The study includes two stages of structure, namely the structure of form and inner structure. Naratology Greimas is a combination of the Levi-Strauss paradigmatic model with the syntagmatic model of Proop. Compared to Proop, the object of the Greimas study is not limited to folktale, but extended to myth. The similarity between Greimas and Proop is to emphasize action rather than to the storyteller. Greimas argues that the concrete is the action that then forms the perpetrator as a false subject (see also Teeuw (1984), Junus (1993), and Hasanuddin WS (2015)).

Based on the study of motives as Proop (1987) and Greimas (1979), the study of the Minangkabau people's legend folktale in West Sumatra continued to classification of the legends folktale based on the similarity of the three types of motifs. This kind of thing was done by Danandjaya (1984) to various folktale from various regions in Indonesia that he collected. Djamaris (1993 and 1994) did the same to the folktale in Sumatra and Kalimantan that he collected. Rusyana (2000) did the same thing not only to the folktale of legends from various parts of Indonesia that he collected, but also to the of myths and fairy tale.

From various reference references as discussed above, the study of legends folktale in this discussion looks special, that is on the object of his study. The object of his study focused only on the legends folktale of Minangkabau people's in West Sumatra. The results of this study, besides of course produce documentation of legends folktale of Minangkabau people's in West Sumatra, also produce classification or categorization. On the other hand, in relation to the development of the world of tourism, the documentation and categorization of legends folktale of Minangkabau people's in West Sumatra will allow it to be utilized to enhance the attractiveness of tourism to the regions of West Sumatra. Tourists visiting West Sumatra not only enjoy nature and culinary, but also can hear and know the legends folktale with the area they visit. 


\section{METHODS}

The research that is the basis of this article is qualitative research, research done by not men use figures and statistical data processing, but prefer the appreciation of researchers to interaction between concepts that are being studied empirically. A study conducted with the intent to understand the phenomenon of what is experienced by the subject of research such as behavior, perception, motivation, action, holistically, with a specific context that is natural, and by utilizing scientific methods.

This research is a research that produces descriptive data in the form of written or oral words of people and behavior that can be observed, depending on the observation on humans, both in the region and in terminology. This research prioritizes the natural setting and is done to present the world social, and perspectives in the world in terms of concepts, behaviors, perceptions, and human issues being studied.

Data of this research is the oral literary category data legends folktale of Minangkabau people's in West Sumatra. Data collection is done in two stages. The first stage, the inventory stage through literature study (document analysis) and the recording of oral literature legends folktale of Minangkabau people's in West Sumatra. The data that is directly told by the informant is recorded using a tape recorder. The recordings are transcribed into written form. The results of transcription are then transliterated from the Minangkabau language into Indonesian. The second stage, the collection of data about the story environment, including the views and philosophy of life, as well as the life values of the speakers community associated with the oral literature of legends folktale of Minangkabau people's in West Sumatra. Data about of the story telling environment is collected through recording, observation, and interview techniques.

\section{FINDING AND DISCUSSION}

The findings of this research, the legends folktale of Minangkabau people's in West Sumatra, based on the motive structure, and done by Proop (1928, 1967, 1987), Greimas (1979, 1990) Danandjaja (1944), and Rusyana (2000), can be categorized in four types of folklore categories of legends folktale. The four categories of legends fokltale of Minangkabau people's in West Sumatra are referred to as (1) folktale of religious legends, (2) folktale of the supernatural legends, (3) folktale of personal legends, and (4) folktale of local legends. Especially for the fourth category, it can also described its subcategories, namely (a) subcategories the origin of events and the naming of places due to topography, (2) subcategories of the origin of events and names of places associated with ungodly children to his mother, (3) subcategories the origin of events and names of places associated with the supernatural things. The interesting thing about this is that the legends folktale of Minangkabau people's of the supernatural categories has very little to collect. If found, the stories of these people are involved with the local legends about the event and the naming of the place. Temporary suspicion of these findings is that the Minangkabau people of today's generation have less interest in passing the story of the unseen nature category because the belief in the supernatural has been greatly reduced.

The folkltale of religious legend, the legend of the meritorious and main people in the development of Islam in West Sumatra can be mentioned, among others, folktale about Sheikh Burhanuddin in Ulakan Padangpariaman District, Sheikh Katik Sangko on Angso Duo Island of Padangpariaman District, Sheikh Abdullah (Baliau Halaban) in Lareh Sago Halaban of 50 Kota District, Syekh Sulaiman Arrasuli (Inyiak Canduang) in Canduang of Agam District, Sheikh Muhammad Jamil Jaho (Angku Jaho) in Jaho of Tanah Datar District, Sheikh Lubuak Ipuah in Kuraitaji of Padangpariaman District, Sheikh Muhammad Sa'ad al-Khalidi (Sheikh Mungka) in Mungka of 50 Kota District, Tuanku Saliah in Sungai Sariak of Padangpariaman District, Tuanku Nan Renceh in Kamang Mudiak of Agam District, Sheikh Muchsin in Sumangek of Solok District, Sheikh Ibnu Abbas in Sungai Balang of Padang City, and Sultan Muhammad Syah in Siguntur Sitiung of Dharmasraya District. Apparently from the mention of the name of this religious legend is divided into three mentions, namely the title Sheikh, Tuanku, and Sultan. The mention of the Sheikh is the most dominant. This can be further investigated in a separate study of the honorific title of the Minangkabau religious legend in West Sumatra.

The folktale category of the supernatural legends, the folktale that is considered to be really happening and once experienced by someone to affirm the superstitious truth is as follows, the folktale of Bukik Sopan in Parik Malintang of Padangpariaman District, Inyiak Gulambai in Sumangek of Solok District, Magek Manandin in Saniang Baka Solok District, The Tiger From Harau Valley in Harau of 50 Kota District, and Ghost Suluah in Tanah Sirah Lubuak Bagaluang of Padang City. The story of the people of othersupernatural legends is a story relating to the occurrence or naming of places, namely folktale Bukik Talio in Taram of 50 Kota District, Bukik Posuak in Maek of 50 Kota District, Rumah Gadang Bendang in Muaro Labuahof South Solok District, Long Reef in Lasi Tuo Canduang of Agam District, Keramat Aripan in Aripan of Solok District, Angkek-angkek Stone in Sungayang of Tanah Datar District, Danau di Atas and Danau di Bawah in Gumanti Valley of Solok District, Sungai Janiah in Sungai Janiah of Agam District, Bujang Sembilan in Maninjau of Agam District, Bujang Sembilan in Paninggahan of Solok District, and Kuburan Panjang in Padangpariaman District. Based 
on these findings, it seems that the folktale of the supernatural legend of the Minangkabau people's in West Sumatra who are still inherited to the next generation is the folktale of the supernatural which is related to the occurrence and naming of the place.

The story of the folktale of personal legends, the folktale of certain figures as the main person, the folktale Datuak Sarian in Timpeh of Dharmasraya District, Tuanku Gaek in Kasiak Koto Sani of Solok District, Tuanku Buyuang Kiramaik in Kampuang Paneh of Padangpariaman District, Mak Ana Mantari in Talang of Solok District, Sutan Basa Tabib in Lawang Matur of Agam District, Malin Bongsu in Tigo Lurah of Solok District, and Haji Subandi in Sitiung of Dharmasraya District. These personal names mentioned can be referred to or existed. This personal legend by the people is regarded as a personal that they respect because their presence is very beneficial to society. Folktale of this category is still not much to be collected. It needs special research for this because it is important for the solidity of the people if they have a role model that characterizes as the identity and pride of the community.

Category of folktale of local legends, ie folktale associated with a place, topography, name, and about the origin, which is about the origin of the name of the place among others fokltale Sungai Antuan in Mungka of 50 Kota District, Korong Gadang in Kuranji of Padang City , Kasatabantang in of Pesisir Selatan District, Batu Kalang in Padang Sago of Padangpariaman District, Kebon Rejo in Lubuk Kilangan of Padang City, Gunuang Pangilun in Gunuang Pangilun of Padang City, Batu Busuak in Pauah of Padang City, Lubuak Godang in Koto Balingka of Pasaman Barat District, Junjuang Sirih in Junjung Sirih of Solok District, Kampuang Guo in Kuranji of Padang City, Simpang Tonang in Simpang Tobang of Pasaman District, Batu Ajuang Batu Tagak in Sijunjung District, Lubuak Tarok in Lubuak Tarok of Sijunjung District, Lubuak Gadang in Lubuak Gadang of Sijunjung District, Tanah Bato in Tanah Bato of Sijunjung District, Batu laweh in Solok District, Batu Jajak Tikam in Padangpariaman District, Ampek Koto Tanjuang Rayo in Tanjung Raya Maninjau of Agam District, Sari lamak in Harau District 50 Kota, Lubuak Baku in Talawi Sijunjung Regency, Lurah Sago in Harau of 50 Kota District, Limau Manih in Lubuk Kilangan of Padang City, Tarok in Baso of Agam District, and Nagari Cupak in Solok District. Folktale of local legends about the ungodly children among others fokltale, Malin Kundang in Air Manis of Padang City, Batu Manangih in Ngalau of Payakumbuh City, Batu Tagak in Lubuk Minturun of Padang City, Batu Kutu in Sungai Sirah Of Pesisir Selatan District, Awang Tingkuluak in Sungai Sariak of Padangpariaman District, Si Boko in Sungai Pisang of Padang City, Batu Manangih in Sungai Tarab of Tanah Datar District, Batu Lengong in Lembah Gumanti of Solok District, Batu Galeh in Sulik Aia of Solok District, Batu Puti in Bayang of Pesisir Selatan District, Bujang Jibun in Surantiah of Pesisir Selatan District, Inyiak Talingo Laweh Gunuang Bongsu in Batipuh of Tanah Datar District, Boncah Tingkuluak in Padang Batang Mungka of 50 Kota District, Payo Tingkuluak in Tanjuang Barulak of Tanah Datar District, and Banca Birunguik in Sungai Pagu of Solok Selatan District.

Based on the results of categorization, theoretically the legends folktale of the Minangkabau people's in West Sumatra can be said to be very complete and varied. It is said to be complete because the categorization of the kind of folktale of legends as formulated by many folktale experts is fulfilled. Although there is no agreement of opinion among scholars that the categorization of folktale will be the same for all cultures in the world, the categorization of Minangkabau legends in West Sumatra is in line with that of Dundes (1971) and Brunvand (1928, 1973 and 1979). First, all types of categorization of folktale legends conducted by researchers in Europe and and America are found in the legend of the Minangkabau people in West Sumatra. Second, compared to other types of folkltale (myths and fairy tales), the legends folktale of the Minagkabau people's is more numerous and varied. This is in line with the alleged folktale researchers, such as Proop (1928, 1967, 1987) Greimas (1979), Dundes (1971), Brunvand (1975), Danandjaja (1984), and Koentjaraningrat (1974) folktale of legends in every culture far more than myths and fairy tale. This is because the folktale of legends, especially local legends, has an unlimited number of basic types. Folktale of local legends will continue to be produced so that it will always increase in number compared to folktale legends that can wander from one area to another (migratory legends).

Of the four categories of folktale legends that were successfully formulated on the Minangkabau folktale in West Sumatra, the seemingly dominant thing lies in the types of categories of religious legend stories and on local legends. Although this has been predictable before, but the number of stories of religious legend that is quite high in number is one of the characteristics of the folktale of its own legend in West Sumatra. This may be related to the Minangkabau belief that Minangkabau are Muslims, if any Minangkabau people embrace another belief, then that person is no longer considered a Minangkabau.

About the story of a local legend that dominates the Minangkabau people's legend in West Sumatra, the thing to get attention is the local legend about the ungodly child. The number of stories is very large in number, even in one region can be found some local legend stories about ungodly children. Interestingly from this as an early prediction, it appears that the motive structure and role function of the boys' lawlessness and the dissent of different daughters. This is unique and requires further research. From this wandering aspect of the rebellious story, there seems to be one archetypal pattern that can be expected that the odyssey of local legend's story about the disobedient in West Sumatra is a monogenesis odyssey, that is, 
one discovery in one Minangkabau region in West Sumatra followed by diffusion process to other Minangkabau territory in West Sumatra, even out of the Minangkabau region of West Sumatra.

The research findings in the form of documentation and categories of folktale of the Minangkabau legend in West Sumatra present another greater possibility for further research on the Minangkabau legend's folktale, or folktale of other types, such as mythical folktale and fairy tales. According to Hadi (2002), Navis (2002), Goodenough (1981) and Sedyawati (2007) earlier will do better because it will be kept authenticity of the story. The longer delayed will be the influence of the outer culture as well as the influence of communication technology tools affecting the narrator in telling the folktale they master.

\section{CONCLUSION}

The legends folktale of Minangkabau people's in West Sumatra contains the values, the philosophy of life, the image of attitude and behavior, and what the Minangkabau people think. Thus, the folktale of Minangkabau people's in West Sumatra is both the knowledge and the local wisdom of the Minangkabau people in living their lives. The wisdom values of the Minangkabau legend's folktale are an invaluable heritage of intangible culture. Like other oral traditions, the Minangkabau legend's folktale has not only a linguistic pragmatic function in speech, but also other wider social functions.

The legends folktale of Minangkabau people's in West Sumatra as an intangible cultural heritage has a social function as well as as a projection system; as a means of ratification of institutions and community institutions; as a means of education of children; and as a tool of coercion and supervisor of the norms of society to always be obeyed. The legends folktale of Minangkabau people's in West Sumatra is a communication tool in terms of concrete community control (social control) to criticize a person or a group that has violated the norms of society. To criticize a person by using folktale is more acceptable and more targeted than a direct rebuke. This is because folktale is not an individual (impersonal). As stated by Bakar (1981), Siegel (1979) and Sulistyowati. (2016), if one feels insinuated by hearing the folktale addressed to him, he can not be angry with the narrator because he is aware that the folktale he is hearing is a legacy of the traditions of his community's ancestors who must be obeyed. Critics who use folktale in these circumstances are supported by a tradition of cultural heritage. In this position, traditition is that play a role, narrator only applies as tell it.

Based on these conclusions, it is recommended that universities, local governments, and government agencies that are linked to cultural heritage should promote research, excavation, and the formulation of the values of a living and growing tradition in the community. This is important because the values of tradition at some point are capable of functioning as theorem in science. Universities, local governments, relevant government agencies, and communities are asked not to ignore and underestimate the oral literature that lives and grows in society. Every society, however modern society really needs a life handling of beliefs and values of wisdom.

\section{References}

Bachtiar, H W. (1992). "Kreativitas: Usaha Memelihara Kehidupan Budaya" in magazine of Analisis Kebudayaan Nomor 01 Volume 1. Jakarta: Depdikbud.

Bakar, J. (1981). Sastra Lisan Minangkabau. Jakarta: Pusat Pembinaan dan Pengembangan Bahasa.

Bakar, J. (1979). Kaba Minangkabau Jilid 1 dan Jilid 2. Jakarta Pusat Pembinaan dan Pengembangan Bahasa.

Barthes, R. (2003). Mitologi (translate by Christian Ly). Bandung: Dian Aksara Press.

Burhanuddin, E. (2009). Kamus Bahasa Minangkabau-Indonesia Balai Bahasa Padang. Jakarta: Pusat Bahasa Depdiknas

Brunvand, J H. (1973). "Book Review, Journal of American Folklore Vol. 86, p. 197-198" in Folklor Indonesia by Danandjaja, 1984. Jakarta: Grafiti.

Brunvand, J H. (1979). Folklor Betawi. Jakarta: Pustaka Jaya .

Danandjaja, J. (1984). Folklor Indonesia: Ilmu Gosip, Dongeng, Dan Lain-lain. Jakarta: Grafiti Pers.

Djamaris, E. (1994). Sastra Daerah di Kalimantan Barat, Tengah, dan Timur: Analisis Tema, Amanat, dan Nilai Budaya. Jakarta: Pusat Pembinaan dan Pengembangan Bahasa.

Djamaris, E. (1993). Nilai Budaya dalam Beberapa Karya Sastra Nusantara: Sastra Daerah di Sumatera. Jakarta: Pusat Pembinaan dan Pengembangan Bahasa.

Goodenough, W H. (1981). Culture, Language, and Society. California: Cummings Publishing Company.

Hadi, W. (2002). "Menyikapi Terjadinya Krisis Identitas dalam Masyarakat Minangkabau” International Coference Paper "Indonesia in Transition". Padang: Fakultas Sastra Universitas Andalas Padang.

Hasanuddin WS. (2015). Ttransformasi dan produksi Sosial Teks Melalui Tanggapan dan Penciptaan Karya Sastra. Bandung: Angkasa

Irianto, S. (2016). "Masyarakat Adat dan Keindonesiaan" in Kompas publish at Friday on 10 June 2016, p. 7. Jakarta: Kompas. 
Jassin, HB. (1983). Sastra Indonesia sebagai Warga Sastra Dunia. Jakarta: Gramedia.

Junus, U. (1993). Dongeng tentang Cerita. Kuala Lumpur: Dewan Bahasa dan Pustaka.

Koentjaraningrat. (2009). Ilmu Antropologi (Revised Edition). Jakarta: Rineka Cipta.

Koentjaraningrat. (1977). Metode-metode Penelitian Masyarakat. Jakarta: Gramedia.

Navis, AA. (2002). "Perkisaran Orientasi Masyarakat Minangkabau dari Masa ke Masa" International Coference Paper "Indonesia in Transition". Padang: Fakultas Sastra Universitas Andalas.

Navis, A.A. (1984). Alam Terkembang Jadi Guru: Adat dan Kebudayaan Minangkabau. Jakarta: Grafiti Press

Rusyana, Y. (2000). Prosa Tradisional: Pengertian, Klasifikasi, dan Teks. Jakarta: Pusat Bahasa Departemen Pendidikan Nasional.

Scholes, R. (1974). Structuralism in Lierature. New Haven: Yale University Press.

Sedyawati, E. (2007). Keindonesiaan dalam Budaya. Jakarta: Wedatama Widya Sastra.

Siegel, J. (1979). Shadow and Sound: The Historical Thought of a Sumatran People. Chicago: University of Chicago Press.

Teeuw, A. (1984). Sastra dan Ilmu Sastra: Pengantar Teori Sastra. Jakarta: Pustaka Jaya. 